\title{
Working with gender in transformative education and supervision: Unpacking the invisible handbag
}

Jude Douglas, Open Polytechnic of New Zealand

\section{Context}

As an educator and professional supervisor, I am physically located in Aotearoa New Zealand and I am also part of a global community of practice. My increased access to online global discourses on both feminism and social work has led me to critically examine my work, in particular in relation to the social justice imperative implicit in my professional roles.

In supervision, a process in which a supervisor "enables, guides and facilitates the social worker[s]..." (ANZASW, 2015, p.1), I'm interested in embedding a transformative function to sit alongside Proctor's (1988) often used categorisation of the functions of supervision as normative, formative and restorative. In a tertiary education programme for professional social work education which includes both online and face-to-face teaching, I'm interested in pursuing a transformative learning agenda, especially in the context of blended learning. As part of this and as a feminist, I'm keen to further explore how I recognise, monitor and manage my own internalised gender biases when working with women students and supervisees. In this sense, gender bias refers to the way I might internalise aspects of the social construction of womanhood as part of my lived experience.

This reflective piece describes this exploration process and findings from my own reflections and from the guided discussion of conference participants during an interactive workshop at the Australian New Zealand Social Work and Welfare Education and Research (ANZSWWER)
Symposium in Auckland, Aotearoa

New Zealand in September 2017.

\section{My critical reflection process}

My understanding of the term critical reflection is the deliberate and active process of discovery of element(s) of the work, usually involving an extended time frame and using different sources of knowledge and challenge. It builds on reflection by incorporating an interrogation of power. This is consistent with Jan Fook's defintion of critical reflection which "includes the many ways power operates, and a person's own power and relationship to it" (Fook, cited in Lishman, 2015, p. 443). Its purpose is always to improve the service I provide by broadening my understanding of why I behave in the way I do and to find or generate new ideas and resources.

With a focus on gender, the questions I chose to interrogate were:
How do I identify, monitor and manage my own internalised gender bias in my work with supervisees and students?
To what extent am I, as a social work educator and professional supervisor, complicit in maintaining unjust gender relations by failing to challenge and teach/supervise in ways which are transformative?

I reviewed literature on feminism and social work, material on learning processes in supervision and education, particularly focussing on the role of supervisor/educator (Beddoe \& Davys, 2016; Mezirow, 2000; Taylor, 2009; Warrell \& Kawalilak, 2011).
AOTEAROA NEW ZEALAND SOCIAL WORK 31(1), 49-53.

CORRESPONDENCE TO: Jude Douglas judedouglas1@hotmail.com 
I also looked at the decolonisation literature (Smith \& Tuck, 2013), material on privilege (Pease, 2010), intersectionality (Crenshaw, 1991), social work and social media (Stanfield, 2015), and hung out in online spaces where these issues are discussed. I took my wonderings to individual and peer supervision and other groups to gain different perspectives. I noted interactions with women students and supervisees which seemed relevant to these questions. For example, the reasons given for late assignments were a rich source of knowledge about the range of issues faced by women students and illuminated gender inequities such as the unequal burden of caring work and both emotional (Hochschild, 1983), and physical labour.

Viv Cree (2018, p. 7), in her commentary in a recent issue of the ANZSW journal that included a section devoted to women and social work, suggests that we must continue to build a feminist theory of social work but cautions that, as we do this:

...we must also always ask questions about things that we take for granted. In social work terms, this means we must interrogate the very ideas and practices that our profession holds dear, and challenge assumptions, both our own and those of others.

I wondered if I was more likely to collude with systemic oppression because I literally didn't always see it if it was related to gender. As part of my own reflections I discovered that I find it easier to identify and respond to oppression related to ethnicity, ability, age and class but that I am sometimes blind to issues of gender, possibly because, as a woman, I have internalised these and see them as "normal". This led me to re-examine the work of Peggy McIntosh (1989) who posited the idea of white privilege being akin to an invisible knapsack of individual and systemic advantage that white people carry around without any awareness that they are carrying it. I wondered if I could use the same processes of deconstruction or unpacking elements of white privilege to look at my own internalised messages about gender, thereby unpacking an "invisible handbag".

At the same time as I was thinking about the messages about gender I had internalised personally, I was acutely aware of all the intersecting oppressions within which my own identity and practice could be situated. These include: my responsibilities under Te Tiriti o Waitangi, my relative privilege as an educated, Aotearoa New Zealand born woman of Dutch, Irish and Scottish ancestry, and my identities as able-bodied, housed, employed, financially secure, and living with heterosexual privilege over many years. Holding this self-awareness about how I hold power in relation to gender issues is vital in my work.

The opportunity to present my initial thinking and process arose as part of the ANZSWWER Symposium held in Auckland in late 2017. I'd captured my initial ideas as a series of images which I spoke to, then briefly examined the notion of the transformative in both supervision and education before involving the group in beginning to unpack, what I have termed, the invisible handbag of gendered identities and then purposively generating possible strategies towards transformative practice within their own contexts.

\section{Strategies for action towards working with gender in transformative ways}

Here is a selction of the potential strategies for action towards working with gender in transformative ways that were generated at the session. Some sources are unknown as the discussion sometimes included quotes for which no source was provided by participants. My analysis of the discussion identified four themes; each is briefly discussed below: 
- the need for critical self-reflection as a starting point: unpacking the invisible handbag;

- the need to provide a safe, yet challenging, environment for learning;

- the need to use evidence about how adults learn; in particular constructivist/ connectivist learning theory;

- the need to use skills which facilitate critical reflection and discourse: questioning, use of tools such as reflective question sets, reflection cycles, role modelling, curating and facilitating access to research/other sources of information.

\section{Critical self-reflection}

As practitioners, we do not operate in a neutral space but are culturally bound. Unless we are able to engage in ongoing critical reflection about our work in every field of practice, we risk perpetuating current systemic inequalities. Critical reflection on ourselves in our work is just a starting point as critical reflection alone does not lead to transformational learning (Mezirow, 2009). We need also to search for meaning inside a critical discourse, what Mezirow (2009, p. 23) refers to as a "thoughtful assessment of beliefs, feelings and values".

\section{A safe, yet challenging, environment}

The space we do this work in needs to be both safe and challenging. We "need to feel comfortable feeling uncomfortable" (Garner, 2007 , p. 405). This aligns with the idea of "supervisor as provocateur" (Cobb et al., 2006), and with the idea that "supervision disrupts practice" (source unknown), ideally something to be negotiated in the initial supervision contract.

In teaching social work, the Māori concept of $a k o$, where teacher and learner roles are sometimes fluid, supports such a learning space. Issues of power need to be unpacked, with student questions central and the teacher role a facilitative one. Taylor (2008) notes the importance of supervisors/teachers showing vulnerability and a willingness to also transform. For example, within one supervision relationship in my practice, I returned to an earlier conversation where my supervisee had disclosed feelings of guilt at not being able to maintain her role as the cook and baker for extended family once she had taken on full-time work. ${ }^{1}$ I hadn't picked up on this at the time because I'd so identified with the feelings of guilt as being integral to working (or studying) women's lives. By my wondering aloud, it gave us the chance to revisit the issues raised and to begin to examine the gendered nature of women's roles. By articulating my own reflective process and admitting I may have missed something important, I was role modelling an important part of practice and I hope, also giving my supervisee permission to do this within her own work.

\section{Using evidence about how adults learn}

Using a constructivist framework, Phillips and Cree suggest supporting students and supervisees to develop their own understandings by asking good questions to build a body of evidence that shows that our experience of the world is still heavily influenced by gender. As Phillips and Cree (2014) state, "it is strategic to leave the analysis fairly open, to allow students to follow up with a desire for further inquiry... why is this so?" (p. 940). In conversation with students who expressed their gratitude to male partners for looking after the children in the weekend so that they could study, I asked whether they thought male partners would routinely express gratitude to their workmates and managers about the fact that they could be at work because their female partner was caring for the children. Usually the response was one of amusement: no they couldn't imagine it would happen this way round. So then I could ask, "Why is this so?" What does this tell us about the perceived roles of men and women and how does this impact on us as women? 


\section{Skills of facilitating critical reflection}

Articulating the process of critical reflection acts a powerful role model for students. This way, students can see critical reflection has value and they can learn the process. One technique is to do what Pease (2010) calls developing a pedagogy of the privileged. This refers to finding a space of relative advantage, or disadvantage, that people can relate to and help them transfer these feelings to an analysis of gender relations. For example, most students are very aware of the stresses that come with juggling multiple roles of worker, carer and student. Because students on placement do not receive any additional funding for the 120 days they are expected to maintain full-time hours of work, there is often a real strain on family finances at this time. In my experience, asking, "How does it feel to be doing two or three jobs, feeling exhausted, and not getting paid?" often elicits feelings of injustice in students which can be then used to help men understand the realities for many working women.

As well as thoughtful questioning, the use of tools such as reflection cycles, reflective learning logs, question sets, storytelling, and the curation and direction to useful sources of information to build an evidence base, are useful. If the supervisor/teacher models the process of empathetic listening and the participants search for meaning together, this constitutes a professional dialogue which can be creative, and can include non-verbal modes. Supervisees and students can be encouraged to locate metaphor and meaning from within their own cultural frameworks. The "What about gender?" questions can, and should be, extended to include all groups - for example, "How might this be different for, say, transwomen?"

Finally, the act of naming it, calling it as gender oppression can be powerful.

\section{Conclusion}

I describe above my motivations, professional context, and the reflective process that led to the generation of, and response to, my two initial questions. This process included an interrogation of literature alongside the interactions I had with students and supervisees as an educator and as a professional supervisor; the use of formal supervision as well as informal networks; and online spaces which served as useful sounding boards for the development of my ideas. I was fortunate to have the opportunity to present my initial thinking to a group of peers who helped generate some further strategies for action.

In answer to the first question - how I identify, monitor and manage my own internalised gender bias in my work with supervisees and students - I now have collated a range of strategies which widen my kete of possible responses and provide a framework to evaluate my work.

The answer to the second question remains more elusive; however, the necessity of engaging in critical reflection as a starting point is, I think, more clear.

To what extent am I, as a social work educator and professional supervisor complicit in maintaining unjust gender relations by failing to challenge and teach/supervise in ways which are transformative?

Challenging unjust gender relations must form part of the work of social workers. It is central understanding in any social justice imperative, in practice, research, supervision and education.

In this piece, I've attempted to examine my own internalised assumptions about gender through documenting a process of critical reflection. The challenge of balancing the attention given to gender with a range of other oppressions experienced in the marginalised populations we work with as social workers, is ongoing. However, strategies and tools we can use to examine and respond are generally useful for any practitioners because of the intersectional nature of oppressions. Ultimately, the value 
of this process is that it serves as a reminder that critical reflection as a starting point must be intrinsic to all practice.

\section{Note}

1 Examples above are constructed by generalising composite experiences and are for illustration only.

\section{Acknowledgement}

Thank you to the participants at my ANZSWWER workshop who helped refine and add to the list of strategies presented here.

\section{References}

Aotearoa New Zealand Association of Social Work. (2015). Supervision policy. Retrieved from https://anzasw.nz/wpcontent/uploads/ANZASW-Supervision-Policy-UpdatedFebruary-2015.pdf

Beddoe, L., \& Davys, A. (2016). Challenges in professional supervision: Current themes and models for practice. London, UK: Jessica Kingsley.

Cobb, M., Fox, D. L., Many, J. E., Mathews, M. W., McGrail, E., Sachs, G.T., Wang, Y. (2006). Mentoring in literacy education: A commentary from graduate students, untenured professors and tenured professors. Mentoring and Tutoring, 14(4), 371-387.

Cree, V. (2018). Feminism and social work: Where next for an engaged theory and practice? A commentary. Aotearoa New Zealand Journal of Social Work, 30(3), 4-7.

Crenshaw, K. (1991). Mapping the margins: Intersectionality, identity politics, and violence against women of color. Stanford Law Review, 43(6), 1241-1299. doi:10.2307/1229039

Douglas, J. (2017, September). Unpacking the invisible handbag: The impact of gender assumptions in transformative education and supervision. Workshop presented at the Australia New Zealand Social Work and Welfare, Education and Research (ANZSWWER) Symposium, Challenging Dominant Discourses, Auckland, New Zealand.

Garner, Y. B. (2007). Open heart and ready hands. Mentoring and Tutoring, 15(4), 403-407.

Hochschild, A. R. (1983). The managed heart: Commercialization of human feeling. Los Angeles CA: University of California Press.

Lishman, J. (2015). Handbook for practice learning in social work and social care (3rd ed.). London, UK: Jessica Kingsley.

Mclntosh, P. (1989). White privilege: Unpacking the invisible knapsack. Retrieved from https://nationalseedproject. org/Key-SEED-Texts/peggy-mcintosh-s-white-privilegepapers

Mezirow, J. (2000). Learning as transformation: Critical perspectives on a theory in progress. San Francisco, CA: Jossey-Bass.
Mezirow, J. (2009). Transformative learning theory. In J. Mezirow \& E. W. Taylor \& Associates (Eds.), Transformative learning in practice: Insights from community, workplace, and higher education ( $\mathrm{pp}$. 18-32). San Francisco, CA: Jossey-Bass.

Pease, B. (2010). Undoing privilege: Unearned advantage in a divided world. London, UK: Zed Publishing.

Phillips, R., \& Cree, V. (2014). What does the "fourth wave" mean for teaching feminism in twenty-first century social work? Social Work Education, 33(7), 930-943.

Proctor, B. (1988). Supervision: A working alliance. East Essex, UK: Alexia Publications.

Smith, L. T., \& Tuck, E. (2013). Decolonizing methodologies. Conference presentation. Retrieved from https://www. youtube.com/watch?v=rlZXQC27tvg

Stanfield, D. (2015, June 11). The sudden importance of social media to social workers in New Zealand [Web log post]. Retrieved from http://www.reimaginingsocialwork. nz/2015/06/the-sudden-importance-of-social-media-tosocial-workers-in-new-zealand/

Taylor, E. W. (2009). Fostering transformative learning. In J. Mezirow \& E. W. Taylor \& Associates (Eds.), Transformative learning in practice: Insights from a community, workplace and higher education (pp. 3-17). San Francisco, CA: Jossey-Bass.

Warrell, J., \& Kawalilak, C. (2011, ??). Transformative learning is not an add-on - It is the essence of adult education. Paper presented at Adult Education Research Conference. Retrieved from http://newprairiepress.org/ aerc/2011/papers/107 